COADY

INTERNATIONAL

INSTITUTE

Occasional Paper Series 
FROM CLIENTS TO CITIZENS:

ASSET-BASED COMMUNITY DEVELOPMENT AS A STRATEGY FOR COMMUNITY-DRIVEN DEVELOPMENT

Occasional Paper Series, No. 4

January, 2002

Alison Mathie, PhD

Coady International Institute

Gord Cunningham, MA

Coady International Institute

St. Francis Xavier University

P.O. Box 5000

Antigonish, Nova Scotia

Canada B2G 2W5 
Published by the Coady International Institute, January 2002

Occasional Paper Series, No. 4

ISSN: $1701-1590$

(C) Coady International Institute. Some rights reserved.

Creative Commons Attribution-Noncommercial-Share Alike 2.5 Canada License http://creativecommons.org/licenses/by-nc-sa/2.5/ca/

All or parts of this publication may be copied and distributed for non-commercial purposes without requesting written permission, provided the author(s) and the Coady International Institute are explicitly acknowledged as the source of the material. Any work adapted from this material must also be made available to others under identical terms.

Coady International Institute Phone: (902) 867-3960

St. Francis Xavier University Fax: (902) 867-3907

P.O. Box 5000 E-mail: coady@stfx.ca

Antigonish, Nova Scotia

Canada B2G 2W5 
From Clients to Citizens: Asset-Based Community Development as a Strategy For CommunityDriven Development

January 2002

Alison Mathie, $\mathrm{PhD}$

Gord Cunningham, MA

The Coady International Institute, St. Francis Xavier University

\begin{abstract}
Asset-based community development $(A B C D)$ is presented as an alternative to needs-based approaches to development. Following an overview of the principles and practice of $A B C D$, five major elements of $A B C D$ are examined in the light of current literature on relevant research and practice. This involves exploring: the theory and practice of appreciative inquiry; the concept of social capital as an asset for community development; the theory of community economic development, such as the sustainable livelihoods approach; lessons learned from two decades of international development in the participatory paradigm; and the theory and practice of building active citizenship engagement and a stronger civil society. How ABCD both reflects recent trends in these areas and stands to benefit from the insights generated from this work is outlined.
\end{abstract}

\title{
From Clients to Citizens: Asset-Based Community Development as a Strategy For Community- Driven Development
}

In recent years, Asset-Based Community Development (ABCD) has caught the attention of North American community development practitioners as an innovative strategy for community-driven development in urban neighborhoods and rural communities. It has attracted a small but dedicated following, particularly among those who are disenchanted with the needs-based approach to community development that is so entrenched in government and non-government service delivery. As an alternative approach, the appeal of $A B C D$ lies in its premise that communities can drive the development process themselves by identifying and mobilizing existing (but often unrecognized) assets, and thereby responding to and creating local economic opportunity. In particular, ABCD draws attention to social assets: the gifts and talents of individuals, and the social relationships that fuel local associations and informal networks.

In considering its potential for international development practice, ABCD can also be viewed as a response to global changes in the social, political and economic landscape. In most countries, liberalization policies have resulted in a weakening of the social contract that gave government responsibility for providing program solutions to community problems. At the same time, stronger, accountable forms of governance at the local level, and the emergence of effective civil society, have been front and center in the process of democratization, particularly in countries of the global south. Technological advances in global and local communications provide opportunities for decentralized economic development for some communities. Other communities, meanwhile, struggle for survival, stretching their assets to unsustainable levels. In this period of flux, there is a two-fold challenge at the community level: to create and seize opportunities for sustainable development, and to claim and retain the rights and entitlements of state and global citizenship.

$A B C D$ embraces several ideas and practices that have risen to the surface during this period of flux. The case we make in this paper is that $A B C D$ offers a coherent strategy for tying together these various complementary strands of innovative development agency practice, in both local and international development contexts.

We first provide an overview of the principles and practice of ABCD. We then examine five major elements of $A B C D$ in the light of current literature on relevant research and practice. This involves exploring: the theory and practice of appreciative inquiry; the concept of social capital as an asset for community development; the theory of community economic development; lessons learned from two decades of development in the participatory paradigm; and the theory and practice of building active citizenship engagement and a stronger civil society. We show how ABCD both reflects recent trends in these areas and stands to benefit from the insights generated from this work.

An overview of Asset-Based Community Development

Based on extensive inquiry into the characteristics of successful community initiatives in the U.S., John 
McKnight and Jody Kretzmann at the Institute for Policy Research (IPR) at Northwestern University, articulated $A B C D$ as a way of counteracting the predominant needs-based approach to development in urban America. In the needs-based approach, well-intentioned efforts of universities, donor agencies and governments, have generated needs surveys, analyzed problems, and identified solutions to meet those needs. In the process, however, they have inadvertently presented a one-sided negative view, which has often compromised, rather than contributed to, community capacity building.

Kretzmann and McKnight (1993) point out that if the needs-based approach is the only guide to poor communities, the consequences can be "devastating" (p.4). One of the main effects is leadership that denigrates the community. Leaders find that the best way to attract institutional resources is to play up the severity of problems. Local leadership is judged on how many resources are attracted to the community, not on how self-reliant the community has become. Another consequence Kretzmann and McKnight point out is that people in the communities start to believe what their leaders are saying. They begin to see themselves as deficient and incapable of taking charge of their lives and of the community. Not surprisingly, community members no longer act like citizens; instead they begin to act like "clients" or consumers of services with no incentive to be producers.

Yet another consequence of this approach is that local groups begin to deal more with external institutions than with groups in their own community. This reinforces the notion that "only outside experts can provide real help" (p.4) and further weakens neighbour-to-neighbour links. Funding is made available on the basis of categories of needs rather than for integrated approaches which leads to "the much lamented fragmentation of efforts to provide solutions...[This] denies the basic community wisdom which regards problems as tightly intertwined, as symptoms in fact of the breakdown of the community's own problem solving capacities" (p.4). To make matters worse, the bulk of any funding tends to go to the institutions filling the needs. Perversely, these institutions begin to develop a vested interest in maintaining this approach.

In Building Communities from the Inside Out, Kretzmann and McKnight (1993) describe an alternative approach, one that recognizes that it is the capacities of local people and their associations that build powerful communities. The process of recognizing these capacities begins with the construction of a new lens through which communities can "begin to assemble their strengths into new combinations, new structures of opportunity, new sources of income and control, and new possibilities for production." (p. 6)

Experience in the U.S. shows how several communities have mobilized to take action for their economic and social development. Sometimes, this $A B C D$ approach has evolved over a long period of time. For example, in Savannah, Georgia, neighbourhood redevelopment had been going on for more than 25 years, initially through municipal agencies responding to problems identified in local neighborhoods. Over time, however, municipal agencies decided to "lead by stepping back"; communities shifted from being "consumers" of services to "designers" of community programs, and, finally "producers" of community (Kretzmann and McKnight, 1999). Lessons learned from experiences such as these spurred the IPR to lead by stepping back from the outset, and to encourage communities to take charge with confidence in their own capacities. Communities are helped to build an inventory of their assets and are encouraged to see value in resources that would otherwise have been ignored, unrealized, or dismissed.

Such unrealized resources include not only personal attributes and skills, but also the relationships among people through social, kinship, or associational networks. By mobilizing these informal networks, formal institutional resources can be activated -such as local government, formal community-based organizations, and private enterprise. In fact, the key to $A B C D$ is the power of local associations to drive the community development process and to leverage additional support and entitlements. These associations are the vehicles through which all the community's assets can be identified and then connected to one another in ways that multiply their power and effectiveness.

Based on the experiences documented by McKnight and Kretzmann, and on initiatives elsewhere that employ a similar approach, we propose that Asset-Based Community Development can be understood as an approach, as a set of methods for community mobilization, and as a strategy for community-based development.

As an approach to community-based development, it rests on the principle that the recognition of strengths, gifts, talents and assets of individuals and communities is more likely to inspire positive action for change than an exclusive focus on needs and problems. Seeing the glass half-full as well as half empty is not to deny the real problems that a community faces, but to focus energy on how each and every member has 
contributed, and can continue to contribute, in meaningful ways to community development. Focusing on uncovering the merits of all members encourages a spirit of egalitarianism, even in societies that are hierarchical in structure and differentiated by culture, educational background and gender. At its core are associations of community members, both formal and informal. As engines of community action, and as a source of power and leadership, these are considered assets of the community (Greene, 2000).

Accompanying this approach is a set of methods that have been used to inspire a community to mobilise around a common vision or plan. While rejecting any kind of blue-print for ABCD, McKnight and Kretzmann (1993, pp 345) propose a number of steps to facilitate the process, which we have modified slightly to capture the importance of storytelling in ABCD's early phases:

- Collecting stories about community successes and identifying the capacities of communities that contributed to success.

- $\quad$ Organizing a core group to carry the process forward

- Mapping completely the capacities and assets of individuals, associations, and local institutions

- Building relationships among local assets for mutually beneficial problem-solving within the community.

- Mobilizing the community's assets fully for economic development and information sharing purposes

- $\quad$ Convening as broadly representative group as possible for the purposes of building a community vision and plan

- Leveraging activities, investments and resources from outside the community to support assetbased, locally defined development

Finally, $A B C D$ is a strategy for sustainable community-driven development. Beyond the mobilization of a particular community, ABCD is concerned with how to link micro-assets to the macro environment. In other words, there is attention paid to the boundaries of community and how to position the community in relation to local institutions and the external economic environment on which its continued prosperity depends.

\section{$A B C D$ and other asset-based approaches}

The growing interest in ABCD as a strategy for community-based development is in keeping with a noticeable shift in international development agency practice to asset- or strength-based approaches. The sustainable livelihoods approach developed by the Department for International Development (DFID), U.K., (and to some degree by the United Nations Development Program [UNDP]), and the asset-building framework now employed by the Ford Foundation are examples of this. Both of these grew out of a concern that simply promoting income-generating activities was not synonymous with enhancing livelihoods of the poor. Proponents of the sustainable livelihoods approach saw the need to take into account many other factors: the vulnerability context in which the poor find themselves; the strategies that households employ to deal with economic shocks; all the human, financial, social, physical and natural assets of households and the community; and the larger structures and processes (institutions, organizations, policies, and legislation) that shape people's livelihoods.

Asset-building, in the Ford Foundation framework, places a similar emphasis on building an asset-base in households and communities that is transferable across generations. Recognizing that many such assets already exist to some degree in the community, the emphasis is on promoting opportunities for building assets and eliminating structures that limit such opportunities.

While beyond the scope of this paper, a comparative analysis of these approaches, and their compatibility with $A B C D$, warrant further discussion.

\section{Elements of $A B C$}

In the following pages, we examine five elements of $A B C D$ and review the literature on the research and practice associated with these different elements. These elements are listed in Table 1 along with a summary of the theoretical and practical contributions of this research and practice to ABCD, which is elaborated in the text. The order in which they are presented has the following logic:

- $\quad A B C D$ is an asset-based approach that uses methods to draw out strengths and successes in a community's shared history as its starting point for change (as in appreciative inquiry). 
- Among all the assets that exist in the community, ABCD pays particular attention to the assets inherent in social relationships, as evident in formal and informal associations and networks (recognized in the research on social capital)

- $\quad$ ABCD's community-driven approach is in keeping with the principles and practice of participatory approaches development where active participation and empowerment (and the prevention of disempowerment) are the basis of practice.

- $\quad A B C D$ is a strategy directed towards sustainable economic development that is community-driven. Reference to community economic development theory is therefore relevant to the ABCD strategy.

- $\quad A B C D$, as a strategy for sustainable economic development, relies on linkages between community level actors and macro-level actors in public and private sectors. In fostering these linkages, $A B C D$ also fosters active citizenship engagement to ensure access to public goods and services, and to ensure the accountability of local government. It therefore contributes to, and benefits from, strengthened civil society.

Constructing shared meaning: Learning from the practice of appreciative inquiry In the initial phases of $A B C D$, the approach to mobilizing communities has much in common with appreciative inquiry. Appreciative inquiry is a process that promotes positive change (in organizations or communities) by focussing on peak experiences and successes of the past. It relies on interviews and story telling that draw out these positive memories, and on a collective analysis of the elements of success. This analysis becomes the reference point for further community action. As Elliott (1999) emphasizes in the title of his book, conducting Appreciative inquiry is all about Locating the Energy for Change.

Appreciative inquiry draws on theories of knowledge construction and communications, and from lessons learned from educational psychology about the sources of personal and collective motivation. This theoretical base is also an anchor for ABCD, particularly in the initial phases of working with the community.

According to Elliott (1999), practitioners of appreciative inquiry assume that reality is socially constructed, and that language is a vehicle for reinforcing shared meaning attributed to that reality. Communities that have been defined by their problems (malnutrition, poverty, lack of education, corruption) internalize this negativity. Elliott explains:

What the appreciative approach seeks to achieve is the transformation of a culture from one that sees itself in largely negative terms - and therefore is inclined to become locked in its own negative construction of itself - to one that sees itself as having within it the capacity to enrich and enhance the quality of life of all its stakeholders - and therefore move towards this appreciative construction of itself. (p.12)

To achieve this transformation, appreciative inquiry adopts what Elliott (1999) calls the "heliotropic principle" (p.43). Just as plants grow towards their energy source, so do communities and organizations move towards what gives them life and energy. To the extent that memory and the construction of everyday reality offer hope and meaning, people tend to move in that direction. Parents and teachers are familiar with this principle; research demonstrates extensively that children's performance is shaped by teachers' and parents' expectations more than it is by children's own innate ability.

Table 1. Contributions of different research and practice areas to ABCD

\begin{tabular}{|c|c|c|}
\hline $\begin{array}{l}\text { Research or } \\
\text { Practice Area }\end{array}$ & $\begin{array}{l}\text { Theoretical Question } \\
\text { Addressed }\end{array}$ & Practical Contributions To An ABCD Strategy \\
\hline \multirow[t]{3}{*}{$\begin{array}{l}\text { Appreciative } \\
\text { Inquiry }\end{array}$} & How is knowledge constructed? & $\begin{array}{l}\text { How to construct shared meaning and a vision for } \\
\text { change }\end{array}$ \\
\hline & $\begin{array}{l}\text { What are the characteristics of } \\
\text { effective communication? }\end{array}$ & $\begin{array}{l}\text { How to facilitate a process that encourages pride in } \\
\text { past success, minimizes power relations and results } \\
\text { in community members' engagement and commitment }\end{array}$ \\
\hline & $\begin{array}{l}\text { What motivates individuals for } \\
\text { change? }\end{array}$ & $\begin{array}{l}\text { How to "locate the energy for change", focusing on } \\
\text { strengths rather than deficiencies }\end{array}$ \\
\hline Social Capital & $\begin{array}{l}\text { What different forms of social } \\
\text { capital exist in associational life and } \\
\text { how do they affect community }\end{array}$ & $\begin{array}{l}\text { Identifying social capital in associations and informal } \\
\text { networks that can be mobilized for change }\end{array}$ \\
\hline
\end{tabular}




\begin{tabular}{|c|c|c|}
\hline & prosperity? & \\
\hline & $\begin{array}{l}\text { What are the conditions that } \\
\text { strengthen and weaken social } \\
\text { capital formation? }\end{array}$ & $\begin{array}{l}\text { What are the conditions that strengthen and weaken } \\
\text { social capital formation? }\end{array}$ \\
\hline \multirow[t]{2}{*}{$\begin{array}{l}\text { Participatory } \\
\text { Approaches }\end{array}$} & $\begin{array}{l}\text { How is power, ownership and } \\
\text { control of resources distributed } \\
\text { within community, and between the } \\
\text { community and outside agents? }\end{array}$ & $\begin{array}{l}\text { Ensuring that the strengths of all individuals are valued } \\
\text { and legitimated through their equal and active } \\
\text { participation, irrespective of power } \\
\text { imbalancesEnsuring that the process is locally } \\
\text { controlled, and community-driven }\end{array}$ \\
\hline & $\begin{array}{l}\text { What are the characteristics of, } \\
\text { contributing factors for, and } \\
\text { consequences of, empowerment? }\end{array}$ & $\begin{array}{l}\text { How to avoid dependency on the outside agent by } \\
\text { "Leading by Stepping Back" }\end{array}$ \\
\hline $\begin{array}{l}\text { Community } \\
\text { Economic } \\
\text { Development }\end{array}$ & $\begin{array}{l}\text { What are the distinctive features of } \\
\text { endogenous } v \text { exogenous models } \\
\text { for economic development? }\end{array}$ & $\begin{array}{l}\text { How to stimulate endogenous, collaborative group } \\
\text { capacity building for economic development }\end{array}$ \\
\hline \multirow[t]{3}{*}{ Civil Society } & $\begin{array}{l}\text { How does civil society mediate } \\
\text { between government and the power } \\
\text { of capital? }\end{array}$ & $\begin{array}{l}\text { How to optimize the "association of associations" to } \\
\text { act in the interests of strengthening community which } \\
\text { in turn contributes to further economic development }\end{array}$ \\
\hline & How can capitalism be humanized? & $\begin{array}{l}\text { Creating a process by which communities are } \\
\text { "Building conditions under which caring becomes } \\
\text { rational" (Edwards, 1999, p. ) }\end{array}$ \\
\hline & $\begin{array}{l}\text { What are the characteristics of } \\
\text { effective governance? }\end{array}$ & $\begin{array}{l}\text { Identifying external circumstances conducive to } \\
\text { application of } A B C D \text {. }\end{array}$ \\
\hline
\end{tabular}

In Elliott's view, two instruments are central to appreciative inquiry: memory and imagination. While these are flawed from the perspective of conventional inquiry because they lack the hallmarks of objective empiricism, they are effective in constructing a shared history and a shared vision for the future in a community setting. This is then translated into a community action plan and immediate community activity to set the process in motion.

Both $\mathrm{ABCD}$ and $\mathrm{Al}$ struggle against the prevailing problem-focus to community development and its accompanying "deficit mind-set". Schooled as most of us are in identifying, analyzing and providing solutions to problems, a neglect of this analysis may seem naive and misguided, especially if we work for agencies established for a problem-solving mission. Yet such a problem-oriented focus, shared by external agencies and donors alike, may serve to set a negative dynamic in motion whereby communities are overwhelmed by a focus on needs and problems which, in turn, stifle initiative for recovery. Without a doubt, some problems require urgent responses. Other problems, however, may lose their urgency, or be solved indirectly when an unrelated change in activity or circumstance takes place and the energy that was focused on the problem becomes re-focused. Ashford and Patkar (2001.) challenge the problem-solver in all of us by quoting from the analyst Carl Jung:

All the greatest and most important problems of life are fundamentally insoluble. They can never be solved, but only outgrown. This "outgrowing" proves on further investigation to require a new level of consciousness. Some higher or wider interest appeared on the horizon and through this broadening of outlook the insoluble problem lost its urgency. It was not solved logically in its own terms but faded when confronted with a new and stronger life urge (p. 86)

Focusing on strengths and capacities is one way in which communities can outgrow a problem, or redefine its solution as a product of renewed collaborative action. It would be misleading to underestimate the challenges of accomplishing this, however. Power asymmetries, the intrusiveness of ideology, and varying levels of commitment to the process may all frustrate effective communication. Yet, Elliott (1999) argues that the process seems to offer community members a more-powerful opportunity to get involved on a moreequal basis. Role reversals take place in such settings, at least for the duration of the inquiry. Power asymmetries in the routine of everyday life may return, but "the object of the inquiry is to splice stakeholders so firmly in the process that when pre-inquiry hierarchies are re-established, they are in fact qualitatively different. The old ground is simply unavailable" (p.285). 
The potential of associations: Learning from the literature on social capital

At the core of $A B C D$ is its focus on social relationships. Formal and informal associations, networks, and extended families are treated as assets and also as the means to mobilize other assets of the community. By treating relationships as assets, $A B C D$ is a practical application of the concept of social capital.

Despite concerns about the lack of conceptual clarity of social capital (see Frankenburger \& Garrett, 1998; Woolcott \& Narayan, 2000), there is agreement in the literature that social capital is present in the networks, norms and social trust inherent in associations whose members work together in concerted collaborative action. In a literal sense, social capital is the store of good-will and obligations generated by social relations. Looked at in this way, networks, norms, and social trust are all evidence of social relations in which social capital has been generated. Thus, as Woolcott and Narayan point out, in the adage "It is not what you know, but who you know", people are talking about the potential support and assistance that stems from the social relationships they have cultivated or inherited through family or class membership. Like other forms of capital, social capital is a latent asset, and individuals can increase or deplete it depending on where they stand in the reciprocal exchange of social support and obligation.

Woolcott and Narayan differentiate between bonding and bridging social capital. In this categorization, bonding social capital enables people to "get by"; bridging social capital enables people to "get ahead" (see Gitell \& Vidal, 1998; Putnam, 2000 on the origin of these terms). Bonding social capital is evident in the close knit relations of friends and families who can be depended on for basic survival in times of stress. It is bonding social capital, for example, that will be drawn upon by a family with insufficient food for survival, or by a woman whose husband is sick and unable to contribute his share of labour. Bridging social capital provides leverage in relationships beyond the confines of ones own affinity group, or even beyond the local community. Educated relatives in the town may, for example, guarantee a larger loan to accelerate the growth of a small enterprise run by extended family members. Relationships cultivated by a community with local authorities might influence the decision about the location of a road to facilitate marketing.

Applying these ideas to $A B C D$, attention needs to be paid to the potential of community associations to mobilize bonding social capital and to increase bridging social capital. In particular, bridging social capital that links the community to the external environment is crucial for sustained economic development and prosperity. Such diversification of social networks stimulates expanded economic activity, which in turn goes on to generate opportunities for increasing and diversifying stocks of social capital. The challenge is to provide opportunities for the poor - who tend to depend on bonding social capital - to access and increase their stock of bridging social capital and access institutions independently (Woolcott \& Narayan, 2000). For social capital to be realized, however, transactional norms and social trust need to be established. In much the same way as material assets need a regulatory and legal environment in order to be realized as negotiable capital (see De Soto, 2000; IFAD, 2001), social assets can only be capitalized in an environment that shares similar expectations of trust and reciprocity. As Woolcott and Narayan (2000) note:

Weak, hostile, or indifferent governments have a profoundly different effect on community life and development projects, for example, than do governments that respect civil liberties, uphold the rule of law, honor contracts, and resist corruption (p.227).

Because it is a type of "capital", the stocks of social capital will inevitably fluctuate in different circumstances. For example, Putnam (2000) has documented these fluctuations and trends for the U.S. in Bowling Alone: The Collapse and Revival of American Community. For an industrial community in Brazil, Bazan and Schmitz (1997) trace the changes in social capital formation over a 50 year period, and show how some social capital stocks are replenished while others are depleted during particular periods. Social capital through kinship, ethnicity, and localness was important when the community was characterized as a small handcraft economy in the 1950s. By the 1990s, however, the economy was characterized by large-scale specialized production integrated into various export sectors. Consequently, deliberate investment in social capital was taking place along class lines, and within integrated sectors of the economy, rather than according to kinship and ethnicity.

Even within a very short time frame, however, the presence of social capital cannot be taken for granted. Moser's (1998) study of four poor urban communities in Zambia, Ecuador, Philippines, and Hungary documents how, under extreme conditions, some households were pushed beyond the limit of sustaining reciprocity networks; women were reluctant to borrow from neighbours for fear of not being able to repay; and informal credit schemes floundered. Ultimately, increased levels of violence, linked to the economic crisis, further eroded social capital. The perceived increased risk to personal safety led to reduced levels of 
community activity and increased levels of isolationism. These in turn reduced participation in the community-based organizations that had been the focus of community collaborative action.

The literature on social capital often makes reference to Putnam's landmark study of social capital and associational life, and their relationship to economic prosperity in Italy, and his more recent work on community life in the US (1993; 2000). Of importance here are the questions about "The Dark Side of Social Capital" (2000, p.350-367) that he addresses. Given that social capital, like any form of capital, can be directed towards anti-social ends, or towards the promotion of special interests over community interests, what are the circumstances under which social capital can be channeled towards community benefit? Putnam suggests that the full potential of social capital as a community economic engine and as a social and economic equalizer can be realized when bridging social capital links people of different family, ethnic, class, or gender affiliations. When associational life creates such bridges and runs its affairs in horizontal, non-hierarchical fashion, there is the greatest chance of success.

The lessons here for ABCD are once again important. It remains to be seen how effectively associational assets can be mobilized for community interests in situations of extreme poverty and depletion of social capital, or in situations where hierarchical relationships are so entrenched within associational and community life that the motivation to pursue the community's interest is outweighed by the interests of class or caste. Putnam's $(1993 ; 2000)$ findings that social capital is correlated with economic prosperity and with relative social equality is encouraging, but the direction of this correlation now needs to be examined in a variety of social and economic contexts.

\section{Recognizing and Developing Economic Capacity: Lessons learned from Community Economic Development Theory \\ $A B C D$ is a strategy for community-driven economic development. To date, the theorizing of community economic development (CED) relies more on the theoretical contributions of community development than on that of economics. In fact, economic theory fails to recognize the concept of community at all. Classical economic theory demands the free mobility of both labour and capital, and the concept of community gets in the way of this free flow.}

The evolution of CED theory represents a confluence of three different development paradigms: a) developing or improving economic systems and infrastructure; b) developing the economic capacities of individuals; and 3) developing the economic capacities of groups to undertake community economic development. In Figure 1, we show the focus of the development process for each paradigm.

The economic systems perspective sees the only difference between economic development and community economic development as one of scale. In other words CED is merely economic development at the community level. Economic development is equated with economic growth. The main participants are outside experts and the types of initiatives employed tend to involve technological improvements and infrastructure development largely in the hopes of attracting investment and industry. From this perspective the development process is largely exogenous.

The individual capacity building perspective sees CED as the byproduct of the economic success of individuals. "Community" tends to refer more to a "target group" of individuals (usually those economically marginalized) rather than to a geographic locality. According to Diochon (1999), economic development solutions are seen to rest with building the capacity of a community's human resources to exploit the potential of underutilized natural and institutional resources. Collective action may be employed, not as an end in itself but, rather, as a "vehicle though which the institutional base identifies the problems and develops solutions that create innovation and entrepreneurship, more/better jobs, increased wealth and incomes and increased opportunities for personal fulfillment" (Chapter 4, p12). From this perspective the development process can be either exogenous or endogenous. The main actors may be external NGOs or they may be local organizations established to promote individual capacity building.

In contrast, the group capacity building perspective sees collective action as an end in itself. Collective action enables individuals who lack the resources to independently improve their wellbeing to mutually achieve this end. This perspective defines CED as an endogenous process. The main participants are by definition the members of marginalized groups that form to undertake collective action. Examples of these types of initiatives include peasant organizations striving for land reform, producer/consumer co-operatives and credit unions, and the movement for community-based resource management. "However, because it is believed that community economic development will not emerge spontaneously, advocacy is considered 
essential. This role is seen to be best filled by independent community-based groups and agencies who can gain broad-based community participation and establish partnerships with public and private stakeholders from within and outside the community" (Chapter 4, p.13).

In many initiatives for economic development, all three perspectives are represented. Take the field of microfinance for instance. At one end of the development spectrum is the financial systems approach where the emphasis is on reforming existing financial systems (regulation and supervision, the role of central banks, overhauling the mandates and practices of rural development banks etc.). The bulk of microfinance interventions however fall into the individual capacity building category. The main expression of this is the 8,000 or so microfinance institutions that provides financial services to 'clients' - either as individuals or in small groups. And at the other end of the spectrum are the small savings-led microfinance organizations such as Self Help Groups, village banks, savings and credit cooperatives and credit unions that focus on developing the capacity of member-based associations.

Similarly, the enterprise development field includes interventions that range from the industry attraction strategies of the economic systems perspective to the focus on entrepreneurship development and business development services of the individual capacity building approach, to the cooperative and community enterprise models of the group capacity building approach.

As illustrated in Figure 1, ABCD fits most comfortably in the group capacity building camp. In the U.S., one of the most notable examples of an ABCD approach to community economic development is the Dudley Street Neighborhood Initiative (DSNI) in Roxbury, Massachusetts (see www.dsni.org). Group capacity building has been at the center of this strategy: a community land trust that has provided hundreds of affordable housing units; a local merchants' organization that encourages a diverse economic landscape dominated by locally, independently and cooperatively owned businesses; a group of 50 young people trained in urban agriculture; and the Resident Development Institute (which hosts community economic literacy workshops).

This is not to say that $A B C D$ initiatives never involve individual capacity building nor advocate for reform of economic systems. The DSNI has been involved in activities ranging from the training of young entrepreneurs to the lobbying of governments for the power of eminent domain to expropriate vacant land for affordable housing. It is just that the ABCD approach has at its core the notion that communities (in particular local associations within those communities) must drive the development process. The role of outside agencies therefore becomes one of group capacity building to ensure that local associations are defining the community vision and mapping and mobilizing local assets and resources to this end.

Learning about the distribution of power: Lessons from participatory approaches to development A central theme of ABCD is the relocation of power to communities, power that has otherwise been held by external agencies. Attention to power and control has also been at the core of at least two decades of participatory development research and practice, particularly through the NGO sector. Arising as a reaction against mainstream approaches to development that marginalized the poor and powerless, participatory development work has pushed for change that transforms inequitable social relations, whether these are within a community or inherent in the relations the community has with external agencies. The challenge of Chambers (Putting the First Last, 1997), for example, is to ensure that people on the margins are prioritized, and to ensure that participation is genuine and equitable, rather than passive, co-opted or restricted to the relatively powerful (see also the critiques of Pretty, 1994; Woost, 1997; Cooke and Kothari, 2001). In other words, power dynamics within the community and the household (between social groups and between genders, for example) are as much a part of the agenda of participatory approaches as power relations between the community and external institutions.

In recent years, critics have argued that participatory development has become increasingly part of the mainstream of international development practice, largely because of the assumptions about the efficiency benefits of participation rather than for the potential of a participatory approach to result in social transformation. The results of so-called "participatory" initiatives have therefore been mixed. In regards to the relations between the community and external institutions, NGOs and government agencies have often set the terms of community engagement, limiting it sometimes to consultation rather than community decision-making. Although there is often an assumption of evolutionary stages towards decision-making and self-mobilization, experience suggests that NGO involvement can often, inadvertently, stifle that progression; less direct involvement from the outside might have greater chance of success. 
Figure 1. The focus the three development paradigms bring to community economic development, and the nature of the development process under each paradigm

\begin{tabular}{|c|c|c|}
\hline & Development Process & \\
\hline $\begin{array}{l}\text { Focus is on reforming } \\
\text { economic systems }\end{array}$ & $\begin{array}{l}\text { Focus is on the econmic } \\
\text { capacities of individuals }\end{array}$ & $\begin{array}{l}\text { Focus is on the econmic } \\
\text { capacities of groups }\end{array}$ \\
\hline $\begin{array}{l}\text { CED as a means to } \\
\text { ecomomic growth. }\end{array}$ & $\begin{array}{l}\text { CED as a means of } \\
\text { enhancing the capacity } \\
\text { of the poor to become } \\
\text { more self-reliant }\end{array}$ & $\begin{array}{l}\text { CED as a means to foster } \\
\text { individual and collective } \\
\text { empowerment and control of } \\
\text { local resources. }\end{array}$ \\
\hline $\begin{array}{l}\text { Communcity is defined } \\
\text { strictly in terms of } \\
\text { administrative boundaries }\end{array}$ & $\begin{array}{l}\text { Community tends to have } \\
\text { a demographic dimension } \\
\text { - focusing on those who are } \\
\text { ecomonically marginalized }\end{array}$ & $\begin{array}{l}\text { Community is self-defined - a } \\
\text { group that shares a 'common } \\
\text { bond' }\end{array}$ \\
\hline resource privatization & extension services & $\begin{array}{l}\text { community-based resource } \\
\text { management }\end{array}$ \\
\hline financial system reform & microfinance institutions & $\begin{array}{l}\text { village banks, credit unions } \\
\text { savings and credit } \\
\text { cooperatives }\end{array}$ \\
\hline Industry attraction & entrepreneurship development & $\begin{array}{l}\text { cooperatives, community } \\
\text { enterprise }\end{array}$ \\
\hline
\end{tabular}

Where $A B C D$ and the legacy of participatory development intersect is in helping to identify a legitmate role for external agencies in community development so that control over development stays within the communities themselves, but in a climate where inclusive participation is encouraged. Users of the ABCD approach are deliberate in their intentions to lead by stepping back. Existing associations and networks (whether formal or informal) are assumed to be the source of constructive energy in the community. Some NGOs might argue, however, that capacity building in the participatory paradigm is more effective if people are not constrained by cultural norms and practices that are undemocratic or inegalitarian. For this reason they might advocate that new community based organizations should be formed rather than building on existing associational forms that might prejudice the interests of less powerful members. The challenge of encouraging inclusive participation, which may at times be at odds with "leading by stepping back," is therefore one with which practitioners of ABCD will have to wrestle as community-driven development unfolds. 
ABCD stands to gain from the rich resource of tools and methods generated by participatory development practice for community-based research, analysis, planning, and for organizational capacity building. A wealth of literature on women's empowerment and the transformation of gender relations for participatory development is particularly noteworthy. The literature also records extensive experience of scaling-up participatory approaches at the local level to regional and national decision-making systems which can inform the strategy that $A B C D$ uses to create linkages between associations at the community level and local institutions.

By way of exchange, ABCD also has fresh insights to offer NGOs involved in participatory development practice. For example, rather than applying participatory rural appraisal (PRA) tools in the needs-based, problem-solving paradigm, packaged for the convenience of NGO planners, applications of these tools within a strength-based paradigm could be further explored: for example, for the identification and mobilization of community strengths and capacities, and for research and analysis of the community development process.

The importance of civic engagement: Learning from the experience of building civil society In the past 20 years, with a gradual weakening of the state and a corresponding strengthening of global capitalism, there has been a surge of interest in the development of civil society as a mediating force between the responsibilities of government and the power of capital at local, national, and international levels (see Salamon, Anheier \& Associates, 1999).

Civil society has a wide spread. Voluntaristic at its roots, it includes development NGOs, churches, people's movements, unions, village organizations, advocacy groups and many other actors. In its activities, civil society embraces a wide range of social and economic roles including service delivery, cooperative social and economic activity, advocacy, protection of the public interest, and public education. Civil society is thus the vehicle for active citizenship or strong democracy (Barber, 1984). If it is to flourish, it requires the acceptance of basic rights of freedom of association and information, and of the rule of law (see Serageldin, 1995). Efforts to strengthen civil society are therefore inextricably linked to the promotion of accountable governance at local, national, and international levels, and on stimulating participatory decision-making for development. At the local level, participatory decision-making depends on both enhancing the capacities of people who previously have been excluded from decision-making, and on creating the institutional mechanisms for their voice to be heard. For this reason, the strengthening of civil society has often been complementary to government decentralization and participatory governance.

Edwards (1999) argues that civil society plays an essential role in "humanizing capitalism." Two important functions are integrated in this humanizing role: the first is the nurturing of social and economic assets that exist in even the poorest communities; the second is advocating for, and holding governments accountable for, the redistribution of more concrete assets through redistribution of land, employment opportunities, public facilities and services to which the "one billion absolute poor" are entitled. In addition, through humanizing capitalism, civil society can generate "the less tangible assets that enable people to bargain, negotiate and advance their interests"(p. 147) that ultimately leads to "self-belief, human ingenuity, and independence of thought" (p. 148).

This reading of the civil society literature finds resonance with Asset-Based Community Development. Practitioners of ABCD wrestle with both the opportunities and the constraints for economic development, relying on social assets to release community potential. As such, ABCD occupies "the middle ground where the logic of competition meets, and mixes with, the logic of co-operation" (Edwards, 1999, p. 162).

\section{Challenges for ABCD}

A number of questions and challenges need further exploration and monitoring as new initiatives of $A B C D$ unfold. These can be summarized as follows

- $\quad$ Fostering an endogenous process: One of the cardinal principles of ABCD is that it should be a community-driven process. What then should be the role of the external agency? Clearly the role in the initial stages is as facilitator of a process, and as a node in a widening network of connections the community may have with other actors. The challenge is to avoid the level of involvement that can induce dependency.

- Fostering inclusive participation: While ABCD is, in principle, an inclusive process in which the contributions of all are valued and appreciated, this may be more challenging in communities where 
social hierarchy excludes or marginalizes some groups. Of particular concern are the opportunities for women and the opportunities for lower caste or class groups. Neither ABCD nor appreciative inquiry directly confronts the issue of unequal power and its attendant oppressions; instead it tends to appeal to the higher motive of using power to act in the shared interests of the common good, and to uncover the strengths of those who might otherwise be less valued. How ABCD unfolds in different settings will therefore depend on how compatible existing norms and cultural practices are with the principles and values of ABCD.

- Fostering community leadership: Because ABCD is community-driven, and the role of the external agency is at arm's length, leadership to sustain a strength-based approach like ABCD becomes a central issue. As it unfolds in different settings, it will be important to learn about the qualities of essential leadership both in terms of the particular individuals involved and the nature of leadership itself. Is it, for example, an individual or a group of individuals? Is leadership formalized, or is it a function of individual or group initiative at particular times? What kind of associations nurtures the best community leaders?

- Selecting enabling environments: The external environment will influence the capacity of communities to realize their potential. The degree to which regulatory environments and local institutions are fair and responsive, and the degree to which norms of trust and reciprocity extend beyond the associational level are important considerations for the introduction of ABCD. However, in the absence of a conducive environment, it is important to explore whether an ABCD approach may provide the best option for identifying and creating openings in an otherwise hindering environment.

- Handling the fluidity of associations: Over time, and dependent on changes in social and economic circumstances, the form and function of associations and informal networks will change. Users of an $A B C D$ strategy need to understand how these patterns have evolved historically, and the effect of the ABCD process on social relationships and patterns of associations and networks. In particular, the implications of associations becoming institutionalized in an ABCD strategy needs to be considered. Will such institutionalization stifle ABCD, or will new associational forms emerge?

\section{Conclusion: Next Steps}

By outlining $A B C D$ and unpacking its various elements, this paper has served to position ABCD as a promising strategy for community development while highlighting questions to consider when it is applied in different international settings. At the time of writing, several initiatives are underway, some of which are $A B C D$, and some of which are "ABCD-like" in their approach. These include the application of ABCD in rural communities in Southern Ethiopia, the Philippines, and in Kenya by non-government organizations that have learned about ABCD in the last year or so and are interested in exploring its potential. These NGOs are collaborating with the Coady Institute in documenting the ABCD process as it unfolds. In addition, the application of ABCD in Curitiba, Brazil by a collaborative partnership between United Way Canada, Curitiba's City Hall, and Pastoral da Crianca offers the opportunity to document the process in an urban setting.

Finally, it is important to remember that ABCD is not done to communities by ABCD experts. Kretzmann and McKnight's work on ABCD evolved from initiatives that occurred spontaneously in communities and municipalities experimenting with different strategies for change. It is therefore equally important to document cases that are not called ABCD but illustrate similar principles, practices, and outcomes. A case in point is a small rural community in Nova Scotia - once a thriving fishing and farming community - that has marshalled its associational links and individual capacities to recreate itself as a going concern in the local tourist industry (Foster and Mathie, 2001). Without this recognition of spontaneous initiatives, and if the practice of $A B C D$ is co-opted by the NGO sector and delivered to communities, there is a real danger that the strategy will be discredited as a self-serving initiative for external agencies. An important challenge to government and non-government agencies is therefore to avoid this irony by genuinely stepping back, while fulfilling social obligations that are inherent in a government/citizen relationship. This may require radical changes in the culture and practice of these agencies, the institutions to which they are accountable, and the public they serve.

Notes

The authors wish to thank John McKnight, Jody Kretzman, Montasser Kamal, and Roger Wehrell for their comments on an earlier draft of this paper.

\section{References}

Ashford, G. and Patkar, S. (2001) "The appreciative inquiry approach" in Graham Ashford \& and Saleela 
Parker (2001). Enhancing Ownership and Sustainability: A Resource Book on Participation (pp 86-93). International Fund for Agricultural Development (IFAD), Asian NGO Coalition for Agrarian Reform and Rural Development (ANGOC), and International Institute for Rural Construction (IIRR)

Barber, B. (1984). Strong Democracy: Participatory Politics for a New Age. Los Angeles, Ca.: University of California Press.

Bazan, L. \& Schmitz, H. (1997). Social capital and export growth: An industrial community in southern Brazil. Discussion Paper 361. Brighton, Sussex: Institute of Development Studies.

Chambers, R. (1997). Whose reality counts? Putting the first last. London: Intermediate Technology Publications.

Cooke, B. \& Kothari, U. (2001). Participation: The new tyranny? New York: Zed Press Democracy: New Yardsticks for Grassroots Development.

DFID Sustainable Livelihoods Approach Guidance Sheets. Livelihoods Connect (http://www.livelihoods.org/info/info_guidancesheets.html)

Diochon, M. (1997). Entrepreneurship and community economic development: Exploring the link. Durham, .K.: University of Durham.

Edwards, M. (1999). Future positive: International co-operation in the 21st century. London, U.K.: Earthscan Publications.

Elliott, C. (1999). Locating the energy for change: An introduction to appreciative inquiry. Winnipeg, MB: International Institute for Sustainable Development

Foster, M. and Mathie, A. (2001) Situating asset-based community development in the international development context. Available from http://www.stfx.ca/institutes/coady/

Frankenberger, T. \& Garrett, J. (1998). Getting connected: Reducing livelihood insecurity by investing in social capital. Unpublished paper. Available from Care International, Atlanta, GA.

Gittell, R. and Vidal, A. (1998) Community Organizing: Building Social Capital as a Development Strategy. Thousand Oaks, Ca.: Sage Publications

Greene, M. (2000). The power of associations: Not mapping but organizing. Unpublished paper. Available from ABCD Neighborhood Circle Initiative, ABCD Institute, Evanston, IL.

International Fund for Agricultural Development. (2001). Rural poverty report, 2001. The challenge of ending rural poverty. Rome: IFAD

Kretzmann, J. \& McKnight, J. (1993). Building communities from the inside out. Chicago, IL: ACTA Publications.

Kretzmann, J. \& McKnight, J. (1999). Leading By Stepping Back: A Guide for City Officials on Building Neighborhood Capacity. Chicago, IL: ACTA Publications.

Moser, C. (1998). The asset vulnerability framework: Reassessing urban poverty reduction strategies. World Development, 28, 1-49.

Putnam, R. (1993). Making Democracy Work: Civic Traditions in Modern Italy. New Jersey: Princeton University Press. 
Putnam, R. (2000). Bowling alone: The collapse and revival of American commun New York: Simon and Schuster.

Robinson, M. (1995). Towards a new paradigm of community development. Community Development Journal, 30(1), 21-30.

Salamon, L. M., Anheier, H. K. \& Associates. (1999). The emerging sector revisited. A summary-Revised estimates. Baltimore, MD: John Hopkins University.

Serageldin, I. (1995). Nurturing development: Aid and cooperation in today's changing world. Washington, DC: The World Bank.

De Soto, H. (2000). The mystery of capital: Why capitalism triumphs in the West and fails everywhere else. New York: Basic Books.

Woolcott, M., and Narayan, D. (2000). Social capital: Implications for development theory, research, and policy. The World Bank Research Observer, 15 (2), 225-249.

Woost, Michael D. (1997). "Alternative Vocabularies of Development? 'Community' and 'Participation' in Development Discourse in Sri Lanka." R.D. Grillo and R.L. Stirrat (Eds.), Discourses of development anthropological perspectives. New York: Berg.

\section{Biographical Notes}

Alison Mathie has over 25 years experience in the International Development field in participatory development and evaluation, formal and non-formal education, rural and urban women's organizations, and gender analysis of macroeconomic policy. Prior to joining the staff of the Coady Institute in 1997, she was an evaluation consultant to various non-government and multilateral agencies. At the Coady Institute, she teaches in the areas of Participatory Approaches to Development, and Gender Analysis for Policy and Planning. Her current overseas work is in the area of participatory approaches to development, particularly in Asset-Based Community Development. She has lived and worked overseas for ten years, primarily in Papua New Guinea and Nigeria. She has also conducted overseas consulting work in South Asia, South East Asia, the South Pacific and East Africa.

She received a PhD (Program Evaluation and Planning) from Cornell University, a MA (Sociology) from the University of Guelph and a MA (Honours, Geography) from the University of Edinburgh.

Gord Cunningham joined the Coady Institute in 1997, bringing more than a decade of experience in the establishment and management of community-based micro-lending programs. He teaches in the areas of Community Economic Development, Community Economic Analysis, and is the coordinator of the Institute's Certificate Program in Community-Based Microfinance. He works with the Centre for Community-Based Management, a joint initiative of the Coady Institute and the StFX Extension Department. He has also worked on the Institute's successful International Youth Internship Program. Currently, he is leading a Coady initiative to review the potential applications for Asset-Based Community Development approaches within developing countries. He is also helping to create a three-year, capacity-building program for more than one thousand rural savings and credit groups that are members of the Self Employed Women's Association (SEWA) in India.

He received his MA (Rural Planning and Development) from the University of Guelph, and a Bachelor of Environmental Studies in Urban and Regional Planning from the University of Waterloo. 